\title{
11
}

\section{Towards a Progressive Local Development Approach: Insights from Local Community Initiatives in Hungary and Romania}

\author{
Sorin Cebotari and Melinda Mihály
}

\section{Introduction}

High unemployment rates, the falling availability of public transportation, the shrinking quality of locally available education, local shops going out of business, the closing down of post offices, schools or kindergartens, and selective out-migration are all manifestations of peripheralisation, which particularly affect rural communities in Central and Eastern Europe (CEE). Rural settlements across CEE often struggle to find a development path that allows them to reverse these dynamics. In some cases, village-based initiatives aiming to counteract peripheralisation emerge from these settlements. This chapter looks

\footnotetext{
This chapter represents a joint contribution of both authors. Melinda presented the Hungarian case while Sorin introduced the Romanian one. The introduction and policy recommendations are a joint effort of both authors.
}

S. Cebotari $(\bowtie)$

Research Center for Sustainable Development, Faculty of Geography Babeș-Bolyai University, Cluj-Napoca, Romania 
into two examples of such initiatives from Hungary and Romania. In each case, the projects were initiated and managed by the local authorities-local mayors.

While developed by local authorities, we still consider these projects as community-owned. We acknowledge that they might not comply entirely with the definition of a community-owned project in the end. However, given the CEE context, these initiatives dominate the landscape of local development projects and are the closest examples to a community-owned project one can find. Both the Hungarian and Romanian case emerged in areas where development policies failed to reverse processes of peripheralisation. Villages undergoing peripheralisation lose those inhabitants who could become drivers of communitybased local development. On the other hand, local civil society is decreasingly involved in publicly funded, local development projects. For this reason, it is understandable why mayor-led projects dominate the landscape of local development in CEE. The question might rise though whether mayor-led development projects are capable of enabling locals to participate and actively shape local development projects. Our research looks closely into that since local participation is an integral part of locally driven development.

This research presents the development of community-owned projects from CEE and should be considered as complementary to the abundance of studies on community-owned initiatives from Western Europe (Hanley and Nevin 1999; ADAS Consulting 2003; Walker and Devine-Wright 2008; Hargreaves et al. 2013; Seyfang et al. 2013; Becker et al. 2017). It is therefore imperative to consider the developments from CEE in their own context, applying only to a certain degree the terminology and conceptualisations developed for similar studies in Western Europe.

\section{Mihály}

Centre for Economic and Regional Studies, Hungarian Academy of Sciences (CERS-HAS), Leipzig, Germany

\section{Mihály}

Centre for Economic and Regional Studies, University of Leipzig, Leipzig, Germany 
Studying a Hungarian social and solidarity economy (SSE) initiative and a Romanian community-owned renewable energy project (REP), we are primarily interested in the following questions:

- What is the capacity of local initiatives to change the peripheralisation dynamics by enriching the capabilities of local actors to innovate and acquire broader economic and political power?

- To what extent do mayor-led, local development projects foster local participation?

- What can be improved or changed within the existing policy approach towards the development of community involvement in the process of local development, thus increasing the efficiency of development policy?

While formulated separately, all three questions are interlinked and to answer any of them we would have to discuss the other two as well; thus, throughout our research we answer all of them combined. Further on, the chapter introduces our theoretical perspective and main normative argument followed by a short methodological outlook. The fourth and the fifth sections analyse the two cases of community initiatives from Hungary and Romania, respectively. The conclusion summarises the main findings and answers the main points raised in the introduction. In the last section we offer policy recommendations based on our theoretical and empirical materials.

\section{Counteracting Peripheralisation Through Capability-Based Local Development?}

Peripheralised spaces are often simultaneously affected by selective out-migration, shrinking public infrastructure and the decline of local economies. These different manifestations of peripheralisation amplify each other's effects (Kühn 2015). To go against the various manifestations of peripheralisation, the traditional understanding of local development needs to be questioned (Fischer-Tahir and Naumann 2013). 
Economic concerns, such as growth, income and employment have historically dominated the concepts of local development (Armstrong and Taylor 2000; Pike et al. 2007). This traditional local development was commonly the subject of a top-down national spatial policy (Pike et al. 2006, 26), grounded in solid macro and micro economic theories (Crescenzi and Rodríguez-Pose 2011). The priority of economic development left socio-environmental issues lagging (Winter 2016, 131) and contributed to further peripheralisation. Currently, a new approach to local development that brings local agency to the forefront is developing (see Eversole et al. 2014; Evans and Syrett 2007). In the analysis of our case studies we aim to go beyond the economic dimension of local development and shed more light on local actors and better understand the social sustainability of local development projects.

We look at mayor-led local development projects through the lens of a capability approach to understand in what ways local development projects may (or may not) go against the processes of peripheralisation. Within the capability approach it is argued that even if the inhabitants of peripheralised areas get marginalised, they have an agency and are capable of advocating their own interests. Therefore, they cannot be considered passive recipients of development projects (Sen 1999). For this reason, it is important in any local development project to build on the strategies of locals and make them capable of changing their destinies and live with their opportunities (Gébert et al. 2016, 27). As Sen puts it: "Greater freedom enhances the ability of people to help themselves and also to influence the world, and these matters are central to the process of development" (Sen 1999, 18). To advocate one's own interests, one needs basic skills. For this reason, the inevitable element of capability-based local development is to eliminate shortages of certain skills. Thus the idea of empowerment is closely related to deliberative participation (Kesby 2005). For this reason we are particularly interested in the governance of local development initiatives. At the same time we are aware that for marginalised communities it is "often difficult to gain access to processes of political decision-making from which they may be culturally, educationally, and linguistically, as well as physically, remote" (Amin et al. 2002, 17). The exclusion of local citizens from processes of decision-making is striking in CEE. Mészáros, 
a civilian and expert of local (community economy) development projects in Hungary describes the situation as follows:

Discussing trust between each other in an environment where decisionmakers clearly do not trust the competencies of the locals is only theoretical. (Mészáros 2013, 93, translated by the authors).

The lack of involvement of citizens in decision-making during state socialism and later on during the post-socialist period has negatively influenced the development of CEE citizens' civic engagement. Another reason for the low level of civic engagement could be that a high ratio of the population is at risk of poverty and social exclusion $37.3 \%$ in Romania and 28.2\% in Hungary, Eurostat 2016, estimated data for 2015). Those people who have been pushed to the periphery of a society fear for their futures and put most of their energy into developing survival strategies for their everyday challenges. Expecting marginalised people to be societally engaged without supporting them may be unrealistic (Harkai 2006).

Civil society was oppressed during state socialism in CEE and did not become a real partner of the state in the post-socialist period either (Fekete et al. 2017). Compared to Western Europe, civil society is weak and underfinanced in CEE (Fekete et al. 2017; Ciepielewska-Kowalik et al. 2015; Defourny and Nyssens 2014). This already weak civil society is further weakened through getting institutionally excluded from the public funding of local development projects (for Hungary see Kabai et al. 2012; Keller 2011). Mayors are local development actors who are capable of accessing governmental (EU and national) funding in local development policies. Therefore local development projects run by the local municipality are dominant in CEE. For this reason we decided to analyse two different types of local initiatives, both run by local municipalities from two different CEE countries.

Even though in our case study local initiatives are of different types and from different countries, the similarities between the challenges and opportunities encountered in both cases are striking. During our initial inquiry we were surprised by the way in which similar background dynamics were present in both cases, regardless of their type 
or geographical location. While with a limited capacity for generalisability, our research presents a detailed account of the interplay between national policies and locally rooted initiatives. Without using comparative methodology, we present a detailed account of each case, offering a clear understanding of common challenges and similar problems faced by local initiatives. Based on this understanding, we outline a series of public policy proposals that could address the main shortcomings and serve as a guiding agenda for supporting local development initiatives.

\section{Methodological Approach}

We apply storytelling while communicating and conducting our research. Stories are central to human existence and, as Lewis (2011) argued, it may be beneficial to use storytelling in doing and communicating research. Semi-structured interviews provided us a space to listen to the emerging stories of our interview partners and therefore "to give voice to the voiceless" (Lewis 2011, 506), but storytelling is also a better method of communicating our research to a wider audience.

\subsection{Research Methods}

In both cases, we conducted semi-structured interviews with all the involved actors which constituted the basis of our empirical data. This technique allowed us to translate main theoretical concepts into guiding questions while also giving the opportunity to keep an open mind regarding other possible points arising during the interviews. Complementary to that we used participant observation, secondary and primary statistical data in order to acquire a better understanding of the context before and while meeting with the interviewees.

For our interviews, we relied on a snowball sampling technique, using as an entry point the official manager/owner/responsible person from the project. From there on, we tried to map the entire population of involved actors by asking every interviewee to name another involved actor. We repeated the process until no new actors were mentioned. 


\subsection{Case Selection}

Despite the research methods being similar for the two projects, we applied a different means of case selection. The Hungarian case was selected using a two-step case selection method. First we identified the peripheralised areas, relying on existing research on regional polarisation (e.g. Koós 2015; Kovács 2010, 2012; Dusek et al. 2014; Pénzes 2015). After that, "best practice" bottom-up local development initiatives were selected by consulting 12 experts from the field of local development and SSE and by examining awards and "best practice" reports. Finally three cases were selected from those peripheralised villages of Hungary that had the highest deprivation index (Koós 2015). The first of the three selected cases, an organic village farm run by the local mayor, will be introduced in detail further on in this chapter.

The Romanian case was also selected using a two-step case selection method. First we mapped all the villages in which renewable energy projects (REPs) were being undertaken, but in doing so we relied on secondary statistical data. After that we used a phone questionnaire to get in contact with local authority representatives to find projects owned by the local community or projects in which the local community had an important share. Only in 2 of the 68 localities with ongoing projects did the local community own the project. Since we are primarily interested in bottom-up, locally based initiatives we chose to look closer at these two cases. As the technology-community interaction developed similarly in both villages, in this chapter only one REP will be presented. The story of Hustiu ${ }^{1}$ village highlights best the benefits and shortages that are common to both cases.

\section{The Hungarian Case: The Organic Village Farm of Kispatak}

The centralisation of local development in Hungary, which has been ongoing since the second half of the 1990s, had a negative impact on traditional civil society organisations (CSOs) and small- and medium enterprises (SMEs), particularly on their ability to access national and 
EU funding for local development (for a detailed overview see Kabai et al. 2012; Keller 2011). Due to this centralisation process, civil and municipal actors ceased to be interdependent, as the latter gained privileged access to funds for rural development and became unevenly represented in decision-making processes. Therefore, mayors of villages have higher chances of accessing national (such as workfare support) and international funding (such as EU funding), while traditional CSOs are struggling. As a consequence, mayor-led social and solidarity economy initiatives are dominant in remote, rural areas.

To overcome regional inequalities in the 2007-2013 financing period the 33 "least privileged micro-regions" (Leghátrányosabb helyzetü kistéréség, LHH) were privileged in accessing funding for rural development (Government Decree no. 311/2007. [XI. 17.]). However, while the programme was successful in channelling more EU funding into peripheralised areas (Kabai et al. 2012) it was criticised, amongst others, for privileging local mayors too much over other local actors. Czike $(2011,12)$ argues that the first period of the LHH Program became "the playground of the local mayors" and civilians, entrepreneurs or representatives of Roma could not make their voice heard.

\subsection{General Context and Case Description}

To better understand the potential and shortcomings of SSE initiatives in the context of peripheralisation, a mayor-led project, an organic village farm, was purposefully selected from Kispatak, ${ }^{2}$ a small and remote village in Northern Hungary in one of the 33 "least privileged micro-regions" that were privileged in accessing public funding for rural development between 2007 and 2013.

The different manifestations of peripheralisation, including economic and infrastructural shrinking, have been amplifying each other's effect in the village, making it less attractive to middle-class families. Due to the economic crisis in the years after the regime change, the agricultural cooperative-which, as in many other villages of Hungary, was the main employer in Kispatak (see Kovách 2012)—needed to close down in the early 1990s. The likelihood of living in poverty in 
Kispatak is particularly high compared to other settlements of Hungary (Koós 2015, see Map 1). Roma people, who are deeply affected by socio-spatial marginalisation in Hungary (Nagy et al. 2015), are overrepresented in the village. Based on the Community Intervention Plan, $40 \%$ of Kispatak's inhabitants are of Roma origin (Anonymised Source $2011),{ }^{3}$ while the ratio of Roma people at the national level is only $3.2 \%$ (KSH 2013).

In 2007, the mayor of the village set up an organic farm to tackle long-term unemployment and poverty by giving the village a new purpose. The mayor of Kispatak argues that the main challenge his village faces is that it has lost its function, such as producing food for the cities, something that is common for settlements of this size (Interview, Kispatak, 23 March 2016). For this reason, the mission of the initiative is to re-establish this function by producing healthy and environmentally friendly organic food at reasonable prices. Through this activity

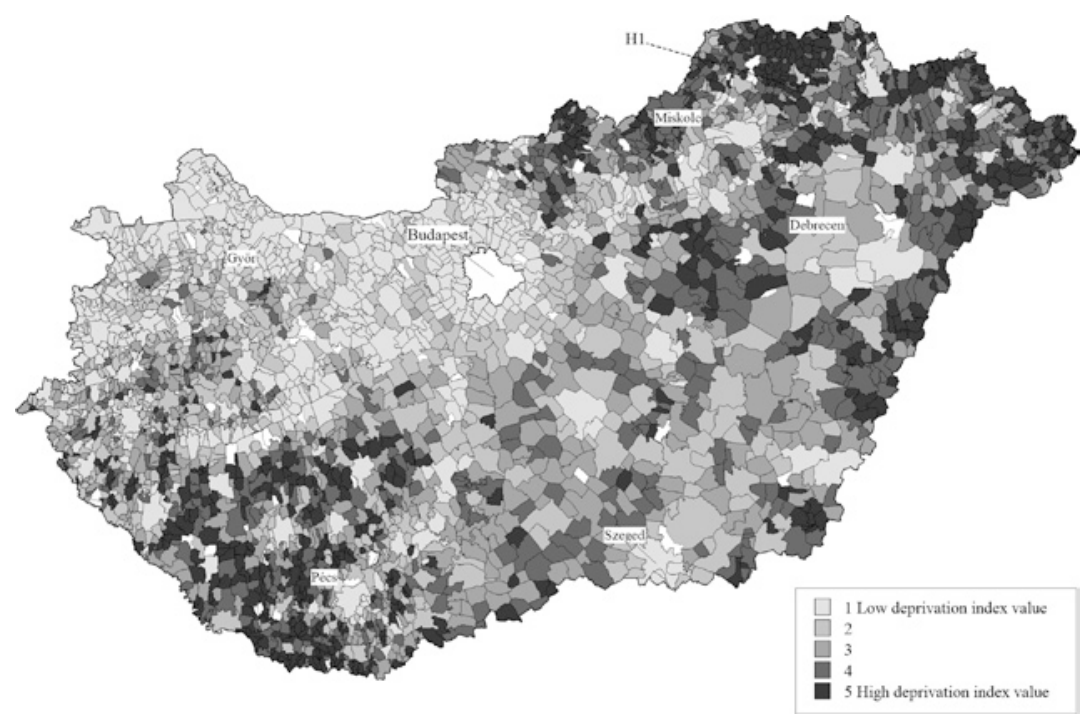

Map 1 Settlement deprivation map of Hungary, 2011 (Source Koós 2015, 64). Kispatak ( $\mathrm{H} 1$, indicated by Mihály) is located in an area where settlements with a high deprivation index are concentrated 
meaningful local employment ${ }^{4}$ would once again become available in the village.

The programme effectively started in 2012 with 25 local volunteers who cultivated 0.6 ha, and grew to 3.5 ha in 2015 and 30 paid employees. In 2012, organic vegetable and fruit production was supplemented with a village shop and handicrafts centre, a food processing manufacture funded by a LEADER grant in 2013, and a herb processing manufacture funded by an ESF grant in 2014.

\subsection{Potential and Shortcomings of the Project}

\subsubsection{Potential Outlined in Best Practice Reports}

[The organic village farm project] became a best practice, not only in the region, but in the whole country. Parallel to this the local identity, the working culture, the self-esteem of the people has positively changed, which is a large step. (Katonáné Kovács et al. 2017, 6-19)

The organic village farm of Kispatak is widely regarded as a "success story" in academic and policymaking spheres. ${ }^{5}$ Articles written about the organic village farm emphasise that the locals do not wait for someone to solve their challenges. Instead, "they" take their own future in their hands. The question might arise whether "they" refers to the whole village or only to some inhabitants? Continuous development or growth was also emphasised in a Best Practice Report referring to the farm as a success story (Anonymised Source 2016). ${ }^{6}$ Specifically, growth in land (more land became available in the project), growth in the number of involved people and growth in the number of activities (the organic farm's shop expanded to include handicrafts, food and herb processing) are highlighted. It may be argued though that the growth of the initiative was not a success in itself, but the result of optimising the use of the resources (EU funding or workfare project), which were made available predominantly for mayors through rural development or employment policies. 


\subsubsection{Dependency on Workfare Project}

Of the three activation programmes (labour market training courses, wage subsidies and workfare programme), public employment (or workfare programme) is the one that explicitly aims to increase the employment of disadvantaged people (Fekete et al. 2017, 27). The programme has grown rapidly in recent years, affecting thousands of people. Workers in public employment are continuously settling into secure income, which is less than the minimum wage in Hungary. A public work employee earns 160 EUR net per month, while the official minimum wage in Hungary was around 230 EUR net in 2016. Only 5\% of programme participants have successfully settled in the primary labour market (Csoba and Nagy 2011). This is by far the worst result among active labour market instruments.

In the case of the organic village farm all employees are employed through public employment (of the total number of workfare employees in the village, 25 work in the organic farm). Only the two experts in sales and gardening are employed through normal labour contracts. By providing low-paid workfare employment for about $32 \%^{7}$ of its active population, the local municipality has become the largest employer in Kispatak. ${ }^{8}$ However the policy aim of public employment is to make local projects independent of public funding; activities financed through the public employment programme mainly mean savings of costs for the local municipalities (Váradi 2016, 30). Even though the organic village farm produces goods for the market and their earned income has nearly tripled in four years (from 3000 EUR in 2012 to 8874 EUR in 2016), 2016 was the first year when the non-profit limited company could officially employ people through conventional labour contracts (the two experts).

From the perspective of the employers, who are mainly local municipalities, ${ }^{9}$ workfare projects provide a cheap local workforce, which is a competitive advantage over organisations that do not have access to workfare projects. Having privileged access to workfare employment, local municipalities can build products and provide services at lower costs than SMEs and traditional civil society organisations, which may 
distort the market. Public work employment can be problematic from the perspective of long-term unemployed people also, as people who are employed in these kinds of SSE projects are paid low wages. The fact that the beneficiaries of the organic village farm must work for less than the minimum wage affects their motivation and self-esteem negatively (Field notes Kispatak, 11 May 2016).

\subsubsection{Providing Meaningful Work for the Workfare Employees}

The idea of the current workfare employment fits very limitedly with the capability-based approach. Since its reform in 2007/2008 public employment has been increasingly embedded in "a turn towards an exclusionary social policy" (Zolnay 2013). People affected by poverty, who are often inhabitants of peripheralised rural areas, get stigmatised in "neoliberal", "radical municipal" and "far right" discourses. Within these discourses people affected by poverty are seen as having had a choice in deciding whether they want to live from transfer payments or conventional employment (Zolnay 2013). Workfare employment was introduced to provide employment instead of social benefits to people affected by poverty. Practical experience in Hungary shows that local governments, the main local coordinators of workfare programmes, are not able to provide real work for less qualified public employees, and often recruit them for "pretend" work. The project of Kispatak deviates from this practice and aims to provide meaningful work for the target group. Through their trading activity their aim is to become less dependent financially on public funding (Interview, Kispatak, 23 March 2016).

\subsubsection{Participation, Power and Decision-Making}

Ethnographic fieldwork in Kispatak has revealed a certain degree of hierarchy between the three branches of the initiative. The organic garden was subordinated to all other branches, such as handicrafts and sales, and fruit and vegetable processing. Those working in the different branches seemed to accept and confirm this hierarchy: 
During a visit to the handicraft house, Marika, an employee of the handicraft and sales branch starts to tell her view about the work in Kispatak. According to her, the workers in the garden are the ones who did not perform 'well enough' to be moved from there. For that reason they had to stay in the garden. Marika does not like to work in the village garden due to the 'crudeness' of the people. They are always swearing, she says. (Field notes, Kispatak, 10 May 2016)

During a visit to Uncle Jenő, who is a Roma and leader of the workers in the organic garden, we met his wife. His wife told us that she was able to "get out" of the organic garden due to her back pain. Now, her responsibility is to plant flowers in the public spaces of the village, which is a much "calmer" job, she said (Field notes, Kispatak, 11 May 2016). In addition to Uncle Jenö's wife, the workers in the organic garden feel that working in the village garden is a punishment for them (Field notes, Kispatak, 11 May 2016).

Workers from all the different branches agreed that working outside of the organic garden is a somewhat privileged position. This might be problematic, as the garden is in the very heart of the organic village farm project, giving jobs for half of the project employees. Tensions inside the organic village farm could be curbed by providing an opportunity for people to rotate within the three different branches. Another way of easing these tensions would be to involve people more in the operation of the village farm, and later on to let them decide themselves in which branch they would like to work.

There are two contrasting views on how certain decisions are made in the organic village farm. The mayor argues that the municipality is responsible for securing financial and non-financial resources, but they let the experts decide on professional questions. However, one of the two experts on the farm shared a story that contrasted with the mayor's description of decision-making processes:

Uncle Karcsi (gardening expert) showed me the farm's lavenders. They were moved a few years ago. He told me that it had been a sore point for him that no one asked his opinion where the lavenders should be replanted when the decision was made. (Field notes, Kispatak, 11 May 2016) 
During our fieldwork in Kispatak we got the impression that the project was rather hierarchic and centred around the mayor, who has invested a lot of energy into the project taking on most of the responsibilities and control over the decisions. The mayor is the one who took the future of the village in his hands in the sense that he is the one who mainly defines the direction of local development (Interview, Kispatak, 23 March 2016).

\subsection{Kispatak, Lessons to Be Learnt}

As a result of re-structuring the agricultural sector, the inhabitants of rural areas became particularly affected by the labour market crisis that characterised the early transition period. As there was a very limited number of alternatives for the unemployed to get a job locally, current local development strategies within CEE need to tackle long-term, in several cases generational, unemployment. Long-term unemployment, public funding and local development are interconnected in Hungary.

By initiating the project in Kispatak, the mayor gained access to national and EU funding and made it available for the community. National funding was channelled through the workfare project and covered employment costs, which are the main fixed costs of the initiative. EU funds contributed to the acquisition of most of the assets. Since 2010, Kispatak has been awarded around 600,000 EUR of EU funding for implementation of the project. Considering how neglected small and remote settlements were in the rural development policy during socialism and after the regime change, the amount of EU funding that Kispatak had access to is justifiable. Nevertheless, it would be of particular importance to open up both project-based funding and funding on a statutory basis for local development actors other than mayors. CSOs or SMEs engaging in local development initiatives should also have equal access to national and international public funding.

In terms of social policy, studies on peripheralisation show that citizens living in peripheralised rural areas cannot be considered exclusively accountable for their poverty. It would be important therefore to transform policy more in line with the capability-based approach. 
Considering that the workfare programme is expensive and ineffective in reaching its aim, namely the integration of long-term unemployed people into the labour market, the state could substitute the workfare programme with a framework to increase the capabilities of the inhabitants of peripheralised areas. Apart from local municipalities, CSOs and SMEs should also become partners of the state in the (re-)integration of the inhabitants of peripheralised areas. All actors involved in local development processes (local municipalities, CSOs and SMEs) must have equal access to funding on a statutory basis. This funding could be given based on the number of long-term unemployed people that the organisation could employ.

\section{The Romanian Case: A Renewable Energy Project}

By researching the relationship between rural communities and REPs ${ }^{10}$ in North-West Romania we expected to find some positive impact on rural development resulting from this relationship. After statistical analysis of large- $\mathrm{N}$ secondary data and the analysis of primary data from the questionnaire completed by local authorities, we found that REPs had no impact on the socio-economic indicators of the host communities. This finding goes against a significant stream of literature that argues that once implemented, REPs could serve as a source of local growth and development (OECD 2012; ADAS Consulting 2003; Del Rio and Burguillo 2008; Cuellar 2012). It was surprising to find that not only was there no sign of a positive impact, but the connection between the project and the local community was absent as well. Local authorities acknowledged the lack of any effect of the project on their well-being, highlighting also that they had little real interaction with the project so they do not expect any benefits for their community to start with. Of the 52 communities that had set up solar power projects, 2 local authorities had a completely different assessment of their relationship with the project and the project's benefits for them. In both cases, local 
authorities owned the solar power project and set each of them up by gaining access to EU structural funds.

Defining community renewable energy projects (COREPs) as projects "where communities (of place or interest) exhibit a high degree of ownership and control, [...] benefiting collectively from the outcomes" (Seyfang et al. 2013), Becker, Kunze, and Vancea highlight a list of possible benefits brought by COREPs. Of them the most important are "addressing climate change, the overall reduction of energy consumption, the protection of biodiversity, sustainable agriculture, a transition town agenda, or social justice and the empowerment of disadvantaged social groups [...] increas[ing] the acceptance of community energy schemes among the population" (Becker et al. 2017, 28). Building on that argument, we claim that the ownership of the project can have a serious and lasting impact on a community's well-being by also influencing local innovation capacity and political engagement. To observe whether it was true for the two community-owned projects we went to these communities and mapped their interaction with the project. The resulting story of the socio-technological interaction uncovers interesting opportunities for alternative, sustainable development at the local level as well as major shortcomings preventing this development.

\subsection{General Context: "Overall... It Looks Great"}

In 2009, the Romanian government increased its support for renewable energy projects in order to achieve Europe 2020 goals (Directive 2009/28/CE). The increased level of financial support led to an impressive development of the renewable energy sector (Cebotari et al. 2017). The share of renewables ${ }^{11}$ in the power generation mix increased from less than $1 \%$ in 2010 to $11 \%$ in 2014 .

The North-West region has the highest number of solar, hydro and biomass power projects, which means that within a general growing trend, the North-West leads in three of four major types of renewable energy generation technologies. Contrasted with quickly rising polarisation within the region (Benedek and Moldovan 2015), it represented an interesting case for our research. 
Development of the renewable energy sector is mostly due to a very generous green certificate support scheme (Legea 220 din 27/10/2008). It was private energy and non-energy actors who invested in renewable energy technologies in order to benefit from high energy prices as well as from green certificates. ${ }^{12}$

Wanting to capitalise more on the fast development of the renewable energy sector, in 2010 the government designed a different initiative aimed at boosting renewable energy generation by encouraging community ownership of REPs. By offering financial assistance to rural authorities, policy-makers expected this initiative to encourage local authorities to develop their own project, through which they could reduce unemployment in rural areas, increase revenues to the local budget and include isolated communities in the national economic circuit (Organismul Intermediar Pentru Energie 2010a). This initiative is an alternative to green certificate allocation; however, the two are mutually exclusive, which means that if you accessed financial assistance for project deployment you cannot apply for green certificates, at least in the first five years of the project's activity.

Of the 172 REPs registered in rural settlements in the North-West region, only two solar power projects owned by local authorities in rural settlements resulted from this initiative (Cebotari and Benedek 2017; Transelectrica 2015). This result raises important questions regarding the policy's efficiency. Given the good intentions and great opportunities for local communities, why do we have so few community owned projects? And, more importantly, how are those projects performing?

\subsection{Looking into Details: "Locally Owned Solar Power Project-Potential and Shortcomings"}

\subsubsection{Locally Owned Projects Without Local Involvement}

To understand the co-evolution of REPs and the dynamics of local communities, semi-structured interviews were conducted with all local actors involved. Contrary to initial expectations, the mayor and the 
vice-mayor of Hustiu were the only persons involved in the process of application, deployment and management of the project from the local community's side. When applying for financial support, they contacted an external company from Oradea ${ }^{13}$ that put together the business case for the project on behalf of the community. Once confirmed, another private company from Cluj-Napoca ${ }^{14}$ set up the project. A third private company from Oradea is now in charge of management and daily activity of the project. So except the mayor and his team, there are no other local actors involved throughout any stages of the project. This initial finding was puzzling since community-owned projects should have a wider engagement of local actors.

\subsubsection{Expected Benefits and Real Payoffs}

When discussing the main reason for setting up a solar power project, the mayor mentioned that there were two complementary rationales: the necessity to decrease the community's public energy spending and the opportunity to access EU funding. He did not expect the project to create local employment or more community engagement from local actors (Interview 1, Hustiu, 26 February 2016). According to Organismul Intermediar Pentru Energie, local authorities (i.e. the local mayor) are the only elective actors who can submit the application for a community-owned project ${ }^{15}$ and who can become the owner of the project (Organismul Intermediar Pentru Energie 2010b). The fact that the mayor did not expect the project to have any impact on local involvement has shaped the way in which the project was implemented. In addition, there is a clear disconnect between the goals of the support scheme, to create employment and local engagement, and the view of local authorities regarding the impact of the project.

However, the project helped Hustiu cut its annual public electricity related spending by $70 \%$. These financial savings allowed larger flexibility for the local budget and the mayor was able to invest in other local projects. Regardless of these benefits, the mayor said that, if given the chance, he would not proceed with the application again for two reasons. First, at the local level, the community did not appreciate the 
effort to deploy the project and, second, at the national level the mayor had to fight a complex and unclear legislation in order to be able to implement the project.

As the mayor pointed out, no one really appreciated the work involved in setting up the project since "they saw no direct benefit to their own pockets. Explaining to them that we could have better side-walks or a renovated kindergarten does not work" (Interview 1, Hustiu, 26 February 2016). The vice-mayor, however, confirmed that there was no strategy to communicate the results of the project to the wider community and that there were no other community actors involved in setting up the project because there was no need for that (Interview 2, Hustiu, 27 February 2016). Also, the private manager of the project said that he believed that there was no real connection between the authorities and the community when it came to discussing the activities and benefits of the project (Interview 3, Hustiu, 27 February 2016).

At the national level, local authorities had to face a difficult challenge. While the project was set up in accordance with the guidelines set by the Ministry of Energy, those guidelines proved to be incompatible with the rules set by Transelectrica, Romania's national transmission and balancing operator. The guidelines also contradict some of the regulations set by Romania's national regulatory authority for energy (ANRE). As pointed out by the mayor, to avoid breaking the funding agreement and be able to benefit from the energy produced in the project, he had to travel several times to Bucharest and get special exemptions in order to operate legally. This negotiation process took more than nine months and proved to be quite difficult for the local authorities since it required in-depth knowledge of energy legislation (Interview 1, Hustiu, 26 February 2016).

In this context, the community-owned project seems to be placed in between Bucharest and the local community. While the rural settlement stands to benefit from the project, the central authorities establish the rules and norms and those can be negotiated or changed only in Bucharest. This leaves the members of the community outside of the project management scheme. There is no communication regarding the benefits of the project, no negotiation over the redistribution of those 
benefits and no real debate over the project's future development. As it stands, local authorities have to involve national regulators to negotiate local development while leaving local actors outside because they lack the time and resources.

\subsection{Visible, Invisible and Lost Benefits}

The mayor concluded that, apart from financial savings, which are an important gain for the local community, there are no other important benefits. If given another chance, the mayor would not take on this opportunity again because the amount of work invested in the deployment of the project was far more costly than the benefits.

Surprisingly, however, the mayor and his team were already working on another application for a micro-thermal plant project that would supply heating to all public buildings while also serving as a possible resource for a local thermal spa. He plans to make this investment partially from the local budget but most money will come from EU structural funds allocated through the national government. He saw no contradiction with his earlier comments because the new project "will not be connected to the national grid, it will be operated locally, we don't have to get involved with anyone from Bucharest, once approved it is with us, here, locally" (Interview 1, Hustiu, 26 February 2016).

The concept the mayor was referring to is "distributed generation", a strategy that allows the producer to consume the energy locally without feeding it to the national grid. In this way, the mayor of Hustiu can avoid all the taxes and levies and manage the village's own energy consumption and production, while also decreasing heating costs. This innovative practice is rooted in his experience with the solar power project, an experience that produced more than simple financial savings. It offered local actors the possibility to learn the most efficient way of producing and consuming energy, forced them to negotiate benefits for their community at the central level and helped them to push their local agenda to national policymakers. In this respect, the solar power project has produced important indirect benefits for local authorities that have 
learned to innovate in the field of energy, got engaged in the energy governance scheme and adapted their future development strategies accordingly.

However, there are lost opportunities as well. Due to both national regulations and local disinterest, local actors are still excluded from the development of REPs. This is a lost opportunity to increase community involvement, create employment opportunities, and develop a local network of entrepreneurs in the field of renewable energy technologies. This is the reason it is still too early to discuss sustainable development enabled through renewable energy technologies. A proactive local authority can play an important role in promoting this type of development, but without wider community involvement projects run the risk of being easily dumped once local authorities change.

\section{Conclusions}

While acknowledging the limitations of case studies and storytelling research, we still believe the two stories presented within this chapter offer an interesting and insightful perspective on local development. So in the end, what did these two cases reveal regarding the potential of local initiatives to reduce peripheralisation and what are the major shortcomings?

As we saw from both stories, mayor-led projects are not opened up to community participation. Since local authorities are favoured when it comes to accessing financing for such projects, it is hardly surprising that they also assume a leading role in project implementation. What is unsettling however is the lack of wider engagement of local actors, even at the individual level. While local authorities believe that they act on behalf of the community, they do not make any visible effort to engage wider participation and ensure growing potential throughout the community. As argued in the theoretical section of this chapter, we view wide community engagement crucial for locally led development in order to counteract peripheralisation dynamics. 
Despite this important drawback, we acknowledge that in the specific economic and social context of CEE, these two cases represent the best of what's possible in terms of community projects. Accepting this reality, we argue that local decision-makers used the existing policy framework to lay the foundations of a locally-rooted initiative that brought financial and non-financial benefits to the local community. Moreover, these projects have positive externalities that could impact peripheralisation processes in the long run, the most important of which being the increasing capacity of local authorities to negotiate with national and regional authorities to shape projects to their own needs and the innovative thinking which allowed them to integrate the project within the local landscape without breaking the funding agreement.

To summarise, the projects as they are now have had little to no impact on deeply rooted peripheralisation dynamics. Nevertheless certain changes that occurred through the two projects might offer some foundation on which innovation and wider engagement can develop. Current, mayor-led projects are closed to the public and not adapted for wide community engagement; therefore they have limited capacity for empowerment. If this challenge can be overcome, the projects may have a better potential to reverse peripheralisation dynamics in those communities.

These two cases are interesting examples of the mismatch between existing conceptualisation of community-owned projects in Western Europe and the practical situation in CEE countries. Both cases offer a good example of an intermediary stage of development, one in which the projects are bound to local communities and are not led by the central government or private actors, but are still halfway towards a wider, participative community engagement. Our contribution takes a bottom-up perspective and considers that in times of rising polarisation local development should be primarily connected to local communities. In this respect, our main contribution to the field lies in the problematisation of two main aspects: first, what is a community initiative in the context of CEE as compared to the examples from Western Europe and, second, can we still consider these types of projects promising for locally rooted development? 


\section{$7 \quad$ Policy Recommendations}

Based on our empirical and theoretical work, we have formulated some policy recommendations to address the main shortcomings of existing national policies. While different with respect to the wider contexts and the specific fields of activity, both stories have several important cross-cutting dimensions that could serve as foundations for public policy recommendations.

\subsection{Reconceptualising "Local Community"}

Existing policies have a static and rigid understanding of local communities. As we saw in both cases, existing legislation favours local authorities, thus it is the local mayor who decides whether a community should pursue a project or not. This is the reason alternative local actors (NGOs, SMEs, CSOs, informal citizen groups) are deprived of the possibility to participate and access financial resources to implement local projects. To change this situation we have to address the following challenges:

\subsubsection{Redefine Local Communities}

All policy initiatives that address rural communities have to enlarge their understanding of "community". Actors such as local SMEs, CSOs or local NGOs should be accepted to apply for governmental funding alongside or in cooperation with local authorities. Enlarging the number of elective actors can ensure wider participation of local communities, diversity of proposals and higher levels of approval for the projects to be implemented.

\subsubsection{Accessibility of Funding (EU and Governmental)}

Once the notion of community is widened, we have to make sure that all relevant actors have equal access to funding. In this respect, public policies that aim to encourage local community projects have to allow 
a wider range of actors to apply and benefit from funding. Moreover, we would argue that successful implementation of a community-owned project requires wide and diversified participation of local actors, and projects that bring together different community actors should be encouraged.

\subsection{Policymaking Is a Two-Way Street}

When discussing local development, we have to acknowledge the importance of local actors and the direct beneficiaries of public policy. The current policymaking structures in Romania and Hungary, which are guided by a top-down logic, have to be re-organised to put the perspective of local actors at the forefront.

An important change to the existing legislation would be to transform the policymaking process by means of a bi-directional mechanism primarily rooted in input from the local community. In order to ensure the required and timely input, any policymaking process should include local actors during three distinct stages: policy design, midterm evaluation and policy adaptation.

\subsubsection{Policy Design}

Before implementing such a change, we need to understand the resources and capacities of local actors. The existing policy discourse follows presumed causal models that are not connected to local realities. Given the fact that the processes of peripheralisation destroy social and human capital, we should engage experts to first focus on creating policies that contribute to the re-building of local human and social capital and then set the context for a participative policymaking process. Any policy encouraging local development first has to target the development of inclusive human and social capital by promoting knowledge generation at the local level.

Considering the lack or availability of local human capital, any policy on local development should start with public discussion of the initiative. Public debates should take place in communities targeted by the 
policy so that all possible stakeholders have the opportunity to influence the policy. With broad involvement of local actors, policymakers could succeed in acquiring the needed local knowledge and input while also ensuring wider public support.

\subsubsection{Policy Evaluation}

Following this initial phase, the primary beneficiaries of the policy should evaluate it. There could be different methods to collect feedback from local actors, but all those methods should rely on information from a wide range of actors. By involving the local community in policy review and evaluation, policymakers would secure feedback directly from the source and would have the possibility to compare locally sourced data with large- $\mathrm{N}$ statistical data.

\subsubsection{Policy Review and Change}

Based on such a midterm evaluation, policies should be revised and adapted and during this policy correction process local actors play a central role because they can provide feedback on the policy's effects and inside information on how to improve the efficiency of the policy.

By involving local actors in policymaking and review processes, the real needs of the community will be assessed accurately.

\section{Notes}

1. The name of the village was changed.

2. The name of the village and the actors of the initiative have been altered.

3. Anonymised citations are used to protect the anonymity of the case study selected.

4. Based on the interview (Interview, Kispatak, 23 March 2016) with the local mayor, the word "meaningful" was also used by him. 
5. Two of the 12 experts that we contacted referred to the village farm as an example of good practice in counteracting the processes of peripheralisation. When searching for the project on Google Scholar, we identified ten scientific articles that referred to the project as good practice, while six of the these ten articles argued that the initiative was socially innovative. Three different policy recommendations on social economy and sustainable rural development highlighted the farm as good practice.

6. A Best Practice Report was prepared and labelled "best practice" by Hungarian scholars and practitioners. It was aimed at decision-makers in the field of sustainable rural development.

7. Own compilation, based on KSH 2011 data and Kajner et al. (2013).

8. As a result, unemployment in the village $(4.35 \%)$ is lower than the national average (NGM 2015).

9. Apart from local municipalities, religious institutions and CSOs are also entitled to employ people through the government's Public Work Program (Frey 2007).

10. This chapter looks specifically at solar power projects. North-West Romania has the highest number of solar power projects implemented at the national level while solar power technology seems to be the most popular within the region as well. The high number of cases offers a good possibility for comparison and cross-case analysis. Complementary to that, the only two community owned REPs are also solar power projects.

11. Much of the electricity generated in Romania comes from hydropower plants. Even though hydro-generation is considered a renewable energy source, according to Romanian legislation only hydro-power plants with a maximum installed capacity of $10 \mathrm{MW}$ are entitled to the renewable energy support scheme. In this context, renewable energy in this chapter refers to all types of renewable energy sources, excluding hydro-power plants with an installed capacity greater than $10 \mathrm{MW}$ unless otherwise stated.

12. The government allocates green certificates to all registered production units that deliver renewable energy to the national grid. Producers can sell these certificates later on to suppliers of energy who have to prove that a part of their energy comes from renewable energy sources.

13. Oradea a city on the border with Hungary and the seat of Bihor county. 
14. Cluj-Napoca is the second biggest city in Romania and is the "unofficial" regional centre for the North-West region.

15. An association of local authorities (asociatie de dezvoltare intracomunitara) can also apply for financing. This association however is composed of local authorities, so in the end it is still the mayor who takes the final decision.

\section{References}

ADAS Consulting. 2003. "Renewable Energy and Its Impact on Rural Development and Sustainability in the UK." URN 03/886. Newcastle: ADAS Consulting for University of Newcastle. http://seg.fsu.edu/Library/ case $\% 20$ of $\% 20$ the $\% 20$ UK.pdf.

Amin, Ash, Angus Cameron, and Ray Hudson. 2002. Placing the Social Economy. London: Routledge.

Anonymised Source. 2011. A Monography on Kispataks Past, Present and Future, Written by Locals.

Anonymised Source. 2016. "Best Practices.” In Szociális Farmok létrehozása Magyarországon-Kézikönyv és fejlesztési javaslatok [Creating Social Farms in Hungary-Handbook and Policy Recommendations], edited by Péter Kajner and László Jakubinyi, 129-56. http://szocialisfarm.hu/files/ Szocialis\%20Farm\%20tanulmany\%203.2.\%20vegleges_nokorr.pdf.

Armstrong, Harvey, and Jim Taylor. 2000. Regional Economics and Policy, 3rd ed. London: Blackwell.

Becker, Sören, Conrad Kunze, and Mihaela Vancea. 2017. "Community Energy and Social Entrepreneurship: Addressing Purpose, Organisation and Embeddedness of Renewable Energy Projects." Journal of Cleaner Production 147: 25-36. https://doi.org/10.1016/j.jclepro.2017.01.048.

Benedek, József, and Aura Moldovan. 2015. "Economic Convergence and Polarisation: Towards a Multi-dimensional Approach." Hungarian Geographical Bulletin 64 (3): 187-203. https://doi.org/10.15201/ hungeobull.64.3.3.

Cebotari, Sorin, and Jozsef Benedek. 2017. "Renewable Energy Project as a Source of Innovation in Rural Communities: Lessons from the Periphery." Sustainability 9 (4): 509. https://doi.org/10.3390/su9040509. 
Cebotari, Sorin, Marius Cristea, Ciprian Moldovan, and Florin Zubascu. 2017. "Renewable Energy's Impact on Rural Development in Northwestern Romania." Energy for Sustainable Development 37: 110-23. https://doi. org/10.1016/j.esd.2017.02.002.

Ciepielewska-Kowalik, Anna, Bartosz Pielinski, Marzena Starnawska, and Aleksandra Szymanska. 2015. "Social Enterprise in Poland: Institutional and Historical Context." ICSEM Working Papers 11. https://www.iap-socent.be/sites/default/files/Poland\%20-\%20Ciepielewska-Kowalik\%20 et $\% 20$ al.pdf.

Crescenzi, Riccardo, and Andrés Rodríguez-Pose. 2011. "Reconciling TopDown and Bottom-Up Development Policies." Environment and Planning A: Economy and Space 43 (4): 773-80. https://doi.org/10.1068/a43492.

Csoba, Judit, and Zita Éva Nagy. 2011. "A magyarországi képzési, bértámogatási és közfoglalkoztatási programok hatásvizsgálata.” In Munkaeröpiaci Tükör, edited by Károly Fazekas and Gábor Kézdi, 113-45. Budapest: MTA Közgazdaságtudományi Intézet, Országos Foglalkoztatási Közalapítvány.

Cuellar, Amanda D. 2012. "Plant Power: The Cost of Using Biomass for Power Generation and Potential for Decreased Greenhouse Gas Emissions." Master thesis, Massachusetts Institute of Technology. https://sequestration. mit.edu/pdf/AmandaCuellar_Thesis_June2012.pdf.

Czike, Klára. 2011. “A kövesút végén. A területi egyenlőtlenségek csökkentése és a romák helyzetének javítása. Jelentés az LHH Program első szakaszának eredményeiről.” Nyílt Társadalom Alapítvány. https://www.opensocietyfoundations.org/sites/default/files/where-paved-road-ends-hungarian-20110301.pdf.

Defourny, Jacques, and Marthe Nyssens. 2014. "The EMES Approach of Social Enterprise in a Comparative Perspective." In Social Enterprise and the Third Sector. Changing European Landscapes in a Comparative Perspective, edited by Jacques Defourny, Lars Hulgård, and Victor A. Pestoff, 42-65. London: Routledge.

Del Rio, Pablo, and Mercedes Burguillo. 2008. "Assessing the Impact of Renewable Energy Deployment on Local Sustainability: Towards a Theoretical Framework." Renewable and Sustainable Energy Reviews 12 (5): 1325-44. https://doi.org/10.1016/j.rser.2007.03.004.

Directiva 2009/28/CE a Parlamentului European și a Consiliului din 23 aprilie 2009 privind promovarea utilizării energiei din surse regenerabile, de modificare și ulterior de abrogare a Directivelor 2001/77/CE și 2003/30/ 
CE. http://eur-lex.europa.eu/LexUriServ/LexUriServ.do?uri=OJ:L:2009:14 0:0016:0062:RO:PDF.

Dusek, Tamás, Réka Lukács, and Irma Rácz. 2014. "Development Differences Among the Regions of Hungary." Procedia Economics and Finance 9: 26477. https://doi.org/10.1016/S2212-5671(14)00028-8.

Eurostat. 2016. 17 October: International Day for the Eradication of Poverty-The Share of Persons at Risk of Poverty or Social Exclusion in the EU Back to Its Pre-Crisis Level—Contrasting Trends Across Member States. Available at http://ec.europa.eu/eurostat/documents/2995521/7695750/ 3-17102016-BP-EN.pdf/30c2ca2d-f7eb-4849-b1e1-b329f48338dc. Last accessed on 26 April 2018.

Evans, Mel, and Stephen Syrett. 2007. "Generating Social Capital? The Social Economy and Local Economic Development." European Urban and Regional Studies 14 (1): 55-74. https://doi.org/10.1177/ 0969776407072664.

Eversole, Robin, Jo Barraket, and Belinda Luke. 2014. Social Enterprises in Rural Community Development. Community Development Journal 49 (2): 245-61. https://doi.org/10.1093/cdj/bst030.

Fekete, Éva G., László Hubai, Julianna Kiss, and Melinda Mihály. 2017. "Social Enterprise in Hungary." ICSEM Working Papers 47. https://www. iap-socent.be/sites/default/files/Hungary\%20-\%20Fekete\%20et\%20al.pdf.

Fischer-Tahir, Andrea, and Matthias Naumann. 2013. "Introduction: Peripheralization as the Social Production of Spatial Dependencies and Injustice." In Peripheralization: The Making of Spatial Dependencies and Social Injustice, edited by Andrea Fischer-Tahir and Matthias Naumann, 9-26. Wiesbaden: Springer.

Frey, Mária. 2007. "A szociális gazdaság megjelenése a hazai fejlesztési stratégiákban és programokban.” In Szociális gazdaság kézikönyv, edited by Judit Csoba, Mária Frey, Éva G. Fekete, Márta Lévai, and Anikó Soltész, 164-78. Budapest: Országos Foglalkoztatási Közalapítvány.

Gébert, Judit, Zoltán Bajmócy, György Málovics, and György Pataki. 2016. "Eszközöktől a jóllétig. A helyi gazdaságfejlesztés körvonalai a képességszemléletben." Tér és Társadalom-Space and Society 30 (2): 23-44. https://doi. org/10.17649/TET.30.2.2752.

Government Decree (17 November 2007): No. 311/2007. (XI. 17.) A kedvezményezett térségek besorolásáról. In Magyar Közlöny 156, 11170-71. Last accessed 29 November 2016. 
Hanley, Nick, and Ceara Nevin. 1999. "Appraising Renewable Energy Developments in Remote Communities: The Case of the North Assynt Estate, Scotland." Energy Policy 27 (9): 527-47. https://doi.org/10.1016/ S0301-4215(99)00023-3.

Hargreaves, Tom, Sabine Hielscher, Gill Seyfang, and Adrian Smith. 2013. "Grassroots Innovations in Community Energy: The Role of Intermediaries in Niche Development." Global Environmental Change 23 (5): 868-80. https://doi.org/10.1016/j.gloenvcha.2013.02.008.

Harkai, Nóra. 2006. Közösség és közösségi munka. Budapest: VEL Kft.

Kabai, Gergely, Judit Keller, and Nándor Németh. 2012. "A foglalkoztatás növelésének célja a kormányzati célok rendszerében. Kistérségi fejlesztések." In Nyugdij, segély, közmunka. A magyar foglalkoztatáspolitika két évtizede, 1990-2010, edited by Károly Fazekas and Scharle Ágota, 47-62. Budapest: Budapest Szakpolitikai Elemző Intézet és MTA KRTK Közgazdaságtudományi Intézet. http://econ.core.hu/file/download/20evfoglpol/kotet. pdf.

Kajner, Péter, András Lányi, András Takács-Sánta, Béla Munkácsy, Gábor Bertényi, Attila Králl, György Jakab, Borbála Karády, Janka Horváth, Emese Bagoly, Máté Vámossy, Patrícia Hegedűs, Gergely Halász, Erzsébet Forrai, Gergely Horváth, Csilla Korinna Benke, Alexandra Tóth, Katalin Kovács. 2013. A fenntarthatóság felé való átmenet jó példái MagyarországonGood Examples of Transition Towards Sustainability in Hungary. MIS-ÖKO Kft. http://humanokologia.tatk.elte.hu/wp-content/uploads/a fenntarthatosag_fele.pdf.

Katonáné Kovács, Judit, Eszter Varga, and Gusztáv Nemes. 2017. "Fókuszban a társadalmi innováció folyamata a magyar vidéken [The Process of Social Innovation-Hungarian Case Studies of Rural Regions]." Északmagyarországi Stratégiai Füzetek-Northern Hungarian Strategic Papers 14 (1): 6-19. http://www.strategiaifuzetek.hu/files/85/Strategiai\%20 fuzetek\%202017-1.pdf.

Keller, Judit. 2011. "Heterarchia és fejlődési pályaváltás. Új elméleti megközelítés a kistérségkutatásban.” Tér és Társadalom-Space and Society 25 (3): 3-26.

Kesby, Mike. 2005. "Retheorizing Empowerment-Through-Participation as a Performance in Space: Beyond Tyranny to Transformation." Journal of Woman in Culture and Society 30 (4): 2037-65. http://doi.org/bsmvw9.

Koós, Bálint. 2015. "A szegénység és depriváció a magyar településállományban az ezredfordulót követően - avagy kísérlet a települési deprivációs index 
létrehozására." Tér és Társadalom-Space and Society 29 (1): 53-68. http:// doi.org/10.17649/TET.29.1.2681.

Kovách, Imre. 2012. A vidék az ezredfordulón. Argumentum, MTA Társadalomtudományi Kutatóközpont (Szociológiai Intézet): A jelenkori magyar vidéki társadalom szerkezeti és hatalmi változásai. Budapest.

Kovács, Katalin. 2010. "Social and Administrative Crises Interlocking: The Misery of Rural Peripheries in Hungary." Eastern European Countryside 16: 89-113. https://doi.org/10.2478/v10130-010-0005-5.

Kovács, Katalin. 2012. “A Cél a 'kiegyenlítés'. Falvakról, térbeli-társadalmi polarizációról, Enyedi Györgyre emlékezve." Területi Statisztika 15 (52/6): 570-82.

Központi Statisztikai Hivatal (KSH). 2013. 2011 évi népszámlálás. 3. Országos Adatok. Available at https://www.ksh.hu/docs/hun/xftp/idoszaki/ nepsz2011/nepsz_orsz_2011.pdf. Last accessed on 26 April 2018.

Kühn, Manfred. 2015. "Peripheralization: Theoretical Concepts Explaining Socio-Spatial Inequalities." European Planning Studies 23 (2): 367-78. https://doi.org/10.1080/09654313.2013.862518.

Legea 220 din 27/10/2008 pentru stabilirea sistemului de promovare a producerii energiei din surse regenerabile de energie. In MONITORUL OFICIAL nr. 577 Din 13 August 2010. http://leg-armonizata.minind.ro/ leg_armonizata/energie/pdf/Legea_220_2008_R_28102011.pdf.

Lewis, Patrick J. 2011. "Storytelling as Research/ Research as Storytelling." Qualitative Inquiry 17 (6): 505-10. https://doi.org/10.1177/10778004 11409883.

Mészáros, Zsuzsa. 2013. “Közösségi gazdaságfejlesztés a gyakorlatban.” ACTA MEDSOC 4: 91-106. https://doi.org/10.19055/ams.2013.4/8-9/8.

Mihály, Melinda. (in review). "Opposing Peripheralization Through Community-Centered Local Development?-Case Studies from Hungary.” ACME: An International Journal for Critical Geographies 15 (1): 129-49.

Nagy, Erika, Judit Timár, Gábor Nagy, and Gábor Velkey. 2015. "The Everyday Practices of the Reproduction of Peripherality and Marginality in Hungary." In Understanding Geographies of Polarization and Peripheralization. Perspectives from Central and Eastern Europe and Beyond, edited by Thilo Lang, Sebastian Henn, Wladimir Sgibnev, and Kornelia Ehrlich, 135-55. New Geographies of Europe. Basingstoke: Palgrave Macmillan.

NGM. 2015. Nemzetgazdasági Minisztérium/Regisztrált munkanélküliek adatai/2015. www.teir.hu. 
OECD. 2012. "Linking Renewable Energy to Rural Development." Executive Summary. Brief for Policy Makers. OECD Green Growth Studies. Paris: Public Governance and Territorial Development Directorate. http://dx.doi. org/10.1787/9789264180444-en.

Organismul Intermediar Pentru Energie. 2010a. "Cerere de propuneri de proiecte. Pentru asistenta financiara nerambursabila acordata din fondurile programului operational sectorial 'Cresterea competitivitatii economice', cofinantat din fondul european de dezvoltare regionala." http://old.fonduri-ue.ro/poscce/fonduri_structurale/pdf/Cerere_propuneri_proiecte_RES_ apel_2010.pdf.

Organismul Intermediar Pentru Energie. 2010b. "Ghidul Solicitantului." Sprijin financiar acordat pentru proiectele de investiţii în valorificarea resurselor regenerabile de energie pentru producerea energiei verzi în cadrul Axei 4 a Programului Operaţional Sectorial Creşterea Competitivităţii Economice. http://old.fonduri-ue.ro/poscce/fonduri_structurale/pdf/Ghid_ IMA_final_martie_2010.pdf.

Pénzes, János. 2015. “A kedvezményezett térségek lehatárolásának aktuális kérdései." Területi Statisztika 55 (3): 206-32.

Pike, Andy, Andrés Rodríguez-Pose, and John Tomaney. 2006. Local and Regional Development. Abingdon: Routledge.

Pike, Andy, Andrés Rodríguez-Pose, and John Tomaney. 2007. "What Kind of Local and Regional Development and for Whom?” Regional Studies 41 (9): 1253-69.

Sen, Amartya. 1999. Development as Freedom. Oxford: Oxford University Press.

Seyfang, Gill, Jung Jin Park, and Adrian Smith. 2013. A Thousand Flowers Blooming? An Examination of Community Energy in the UK. Energy Policy 61: 977-89. https://doi.org/10.1016/j.enpol.2013.06.030.

Transelectrica. 2015. "Contracte de Racordare." http://www.transelectrica.ro/ documents/10179/45094/7productie16.xls/8cac352d-676a-4fbb-9f1130e8d56a1d4d. Accessed 3 March 2016.

Váradi, Mónika Mária. 2016. “Értékteremto közfoglalkoztatás periferikus vidéki terekben.” Esély (1): 30-56. http://esely.org/kiadvanyok/2016_1/2016-1_2-1_Varadi_Ertekteremto_kozfoglalkoztatas.pdf.

Walker, Gordon, and Patrick Devine-Wright. 2008. "Community Renewable Energy: What Should It Mean?” Energy Policy 36 (2): 497-500. https://doi. org/10.1016/j.enpol.2007.10.019. 
Winter, Amanda K. 2016. "Environmental Sustainability? We Don't Have That Here: Freetown Christiania as an Unintentional Eco-Village." ACME: An International Journal for Critical Geographies 15 (1): 129-49.

Zolnay János. 2013. "Tartós munkapiaci kirekesztés, szegénység és társadalompolitikai válaszok-A kutatás kontextusa.” In A szociális segély csökkentésének hatásai a vidéki Magyarországon, 2012-Interdiszciplináris dokumentáció, edited by Katalin Nagy. Budapest: Pro Cserehát Egyesület. http://www.pillangokutatas.bffd.hu/kutatasi-eredmenyek/tanulmanyok.

Open Access This chapter is licensed under the terms of the Creative Commons Attribution 4.0 International License (http://creativecommons. org/licenses/by/4.0/), which permits use, sharing, adaptation, distribution and reproduction in any medium or format, as long as you give appropriate credit to the original author(s) and the source, provide a link to the Creative Commons license and indicate if changes were made.

The images or other third party material in this chapter are included in the chapter's Creative Commons license, unless indicated otherwise in a credit line to the material. If material is not included in the chapter's Creative Commons license and your intended use is not permitted by statutory regulation or exceeds the permitted use, you will need to obtain permission directly from the copyright holder.

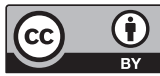

